\title{
Changes in ladybird (Coleoptera: Coccinellidae) communities along a steep pollution gradient in subarctic forests of European Russia
}

\author{
Mikhail V. KOZLOV \\ Section of Ecology, University of Turku, FI-20014 Turku, Finland; e-mail: mikoz@utu.fi
}

Key words. Coleoptera, Coccinellidae, Calvia quatuordecimguttata, abundance, aerial pollution, copper-nickel smelter, diversity, Russia, Monchegorsk, predators, rare species, Salix

\begin{abstract}
Industrial air pollution constitutes a major environmental disturbance, and its impacts on insect communities have considerable implications for ecosystem structure and functions. Existing information on insect responses to pollution generally addresses abundant taxa, whereas few studies examine the effects of pollution on rare species. To begin rectifying this bias, ladybirds (Coleoptera: Coccinellidae) were quantitatively collected annually from 2002-2014 in 13 sites located 0.7 to $39.7 \mathrm{~km}$ from the nickel-copper smelter in Monchegorsk, north-western Russia. Seven of eight recorded species were found only in severely and/or moderately polluted sites. Both Shannon's diversity index and coccinellid abundance decreased with increasing distance from the smelter. Thus, some groups of predatory insects, in particular the Coccinellidae, may benefit from environmental changes caused by severe industrial pollution, whereas the most abundant invertebrate predators generally suffer from such changes.
\end{abstract}

\section{INTRODUCTION}

Insects are extraordinarily diverse and abundant and have significant roles in the majority of terrestrial ecosystems; they are "the little things that run the world" (Wilson, 1987). Therefore, the knowledge of the responses of insects to human activities is crucial for understanding and predicting changes in ecosystem structure and functions following different kinds of disturbances (Lavelle et al., 2006; Maleque et al., 2006).

The influence of industrial pollution on forests has long been recognised as a serious local, regional and global environmental problem (Kozlov \& Zvereva, 2015, and references therein). For decades, ecologists have studied the effects of pollution on terrestrial biota in the surroundings of large industrial areas, and local effects of pollution on different groups of organisms are described in thousands of publications (reviewed by Alstad et al., 1982; Heliövaara \& Väisänen, 1993; Kozlov et al., 2009; Kozlov \& Zvereva, 2011). The recent meta-analysis demonstrated that while the abundance of herbivorous insects generally increases in polluted areas, abundance of predatory invertebrates decreases (Zvereva \& Kozlov, 2010). This pattern is in agreement with the hypothesis that predatory organisms are more sensitive to pollution than herbivores, and that pollution, through selective elimination of predators, creates an enemy-free space for plant-feeding insects (Heliövaara et al., 1982; Selikhovkin, 1985; Zvereva \& Kozlov, 2000).

To what extent do the conclusions of this meta-analysis reflect the patterns existing in nature? This question is far from simple, because a number of biases occurring in the planning, data collection, analysis and publication phases of scientific research are known to substantially influence the outcomes (Pannucci \& Wilkins, 2010). Not surprisingly, quantitative data are generally collected for species that are sufficiently abundant to accurately measure their density with a feasible investment of time and effort. In other words, the information summarized from published studies generally reflects the population dynamics of a limited number of abundant species, whereas the vast majority of species are rare (Gaston, 1994). Thus, we lack information on pollution-induced changes in populations of rare species, which are presumed to be most vulnerable to different kinds of disturbances, including habitat loss and climate change (Lavergne et al., 2005; Sekercioglu et al., 2008), and provide valuable ecosystem functions (Mouillot et al., 2013).

Ladybirds (Coleoptera: Coccinellidae) are important predators that control the densities of sap-feeding insects in many natural and agricultural ecosystems (Hodek \& Evans, 2012). However, ladybirds are infrequent in subarctic forests relative to ants, spiders and bugs, which are the most common arboreal predators in these habitats (Zvereva \& Kozlov, 2000, 2006). The aim of the present study was to check whether the rare predators (Coccinellidae) respond to pollution-induced habitat deterioration in the same way as the abundant predators, i.e. whether they decline with increase in industrial pollution, thus creating enemy-free space for their herbivorous prey.

\section{MATERIAL AND METHODS}

The nickel-copper smelter at Monchegorsk $\left(67^{\circ} 56^{\prime} \mathrm{N}\right.$, $32^{\circ} 49^{\prime} \mathrm{E}$ ), north-western Russia, for decades was one of the largest polluters in the Northern hemisphere. The smelter was started up in 1937 and had no air-cleaning facilities until 1968. The annual emissions of $\mathrm{SO}_{2}$ from this smelter reached a maximum of 278,000 metric tons in 1983 , steadily declined to about 100,000 tons by mid-1990s, dropped to 45,000 tons in 1999 , since when they have remained at about this level. Annual metal emissions into ambient air during the $1980 \mathrm{~s}-1990$ s amounted to $3000-8000$ tons of $\mathrm{Ni}$ and 1000-6000 tons of $\mathrm{Cu}$ annually, but have decreased 


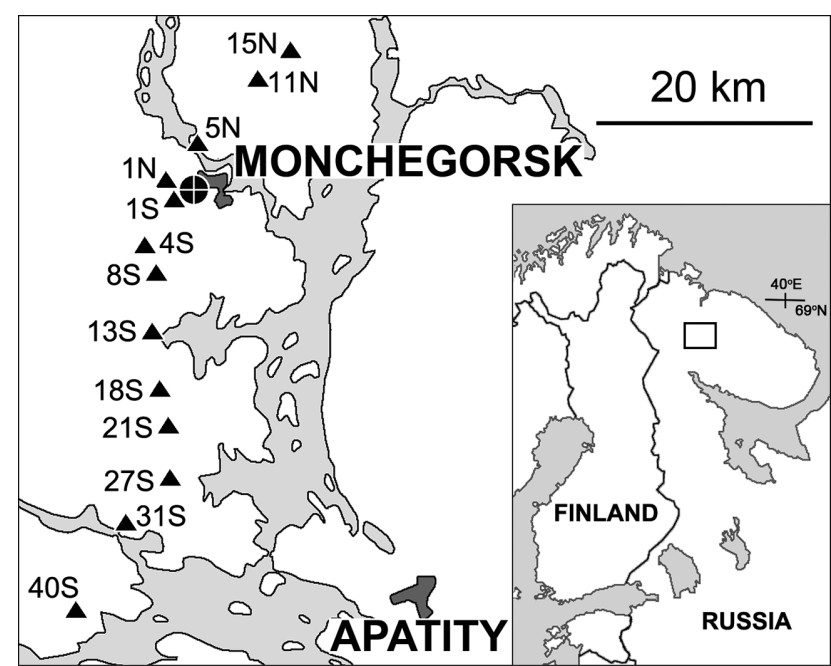

Fig. 1. Location of the study sites (triangles) relative to that of the smelter (crossed black dot). Inserted: location of the study area in Northern Europe.

since then to approximately 500-600 tons of each of $\mathrm{Ni}$ and $\mathrm{Cu}$ in the mid-2000s. The distributions of $\mathrm{SO}_{2}$ and heavy metals follow similar spatial and temporal patterns (Kozlov et al., 2009).

Forests up to $6 \mathrm{~km}$ from the Monchegorsk smelter had died by 1946 . Observations in the early 1990 s revealed forest death in an area of 400 to $500 \mathrm{~km}^{2}$ and visible injuries to conifers were detected up to $50-60 \mathrm{~km}$ away from the smelter. The total area affected by emissions was estimated to exceed $10,000 \mathrm{~km}^{2}$, with over $200 \mathrm{~km}^{2}$ of the previously forested areas converted into industrial barrens - bleak open landscapes with small patches of depauperated vegetation surrounded by bare, eroded land (Kozlov et al., 2009). Despite a reduction in emissions, no natural recovery has yet been observed in the industrial barrens due to legacy effects such as extremely high concentrations of heavy metals and shortage of nutrients in the thin, eroded soil (Zverev, 2009).

Data were collected in 13 sites located 0.7 to $39.7 \mathrm{~km}$ from the smelter (Fig. 1). The larger extent of the polluted zone and, consequently, the study area to the south, compared to the north (Fig. 1), results from the spread of aerial pollution by predominantly north winds during summers. Study plots were set up in localities representing different stages of pollution-induced deterioration of Norway spruce [Picea abies (L.) Karst.] forests. Detailed descriptions of study sites can be found in Zvereva et al. (1995) and Zvereva \& Kozlov (2000). The concentrations of principal pollutants in this study area correlate strongly with the proximity to the smelter, and diversity of plant species decreases markedly with increasing level of pollution (Kozlov et al., 2009).

Ladybirds were collected in early summer (11-30 June; median date 19 June) of 2002-2014, by three 10-min surveys of willow bushes at each site. Willows were selected for this study because they tolerate high levels of pollution and therefore tend to become dominant in heavily polluted habitats, including industrial barrens (Kozlov \& Zvereva, 2007). The most common species in the study area were Salix myrsinifolia ssp. borealis (Fries.) Nasar., S. caprea L. and S. phylicifolia L. The mountain birch [Betula pubescens ssp. czerepanovii (Orlova) Hämet-Ahti] was also abundant in the study area, even in heavily polluted sites; however, ladybirds do not occur on mountain birch in this region. Similar efforts during 2002-2004 resulted in 50 specimens of Coccinellidae collected from willows and a single specimen of Calvia quatuordecimguttata (L.) collected from mountain birches; therefore sampling of birches was discontinued.

All counts were performed on days when the weather was good (no rain, clear sky, slight or no wind). All sites were surveyed on the same day, between 11 a.m. and 19 p.m. Daily values of temperatures recorded at the meteorological station in Monchegorsk were obtained from the Lapland Biosphere Reserve (2002-2004) and from the web-based archive (www.rp5.ru; 2005-2014) and were used to calculate the sums of temperatures above $5^{\circ} \mathrm{C}(\mathrm{dd} 5$ hereafter) accumulated up to the day on which the beetles were collected. In all years, observers walked along the same pre-defined paths and collected all the adult ladybirds found on willows along the way. A total of four observers participated in the surveys in 2002-2014; about $90 \%$ of the data were collected by the author jointly with $\mathrm{V}$. Zverev.

The collected ladybirds were pinned and their identifications confirmed by H. Silfverberg (specimens collected in 2002-2011) and J. Mattila (in 2012-2014). Voucher specimens are deposited in the Natural History Museum (Helsinki).

The among-year and among-site variation in abundance of ladybirds was revealed by a Kruskal-Wallis test. Then the numbers of ladybirds collected during 2002-2014 were summed by species and study site. Shannon's index $\left(H=-\sum\left[p_{i} \times \ln p_{i}\right]\right.$, where $p_{i}-$ the proportion of $i$ th species of the total abundance), was calculated for each study site and used as a measure of diversity. The effects of pollution were tested by calculating Spearman rank correlation coefficients between the site-specific numbers of specimens and

TABLE 1. Characteristics of the study sites

\begin{tabular}{|c|c|c|c|c|c|}
\hline Site code $^{1}$ & Latitude, $\mathrm{N}$ & Longitude, $\mathrm{E}$ & Altitude (m a.s.1.) & Distance from smelter $(\mathrm{km})$ & Habitat type $^{2}$ \\
\hline $15 \mathrm{~N}$ & $68^{\circ} 02^{\prime} 40^{\prime \prime}$ & $33^{\circ} 01^{\prime} 41^{\prime \prime}$ & 180 & 14.6 & DCF \\
\hline $11 \mathrm{~N}$ & $68^{\circ} 01^{\prime} 06^{\prime \prime}$ & $32^{\circ} 57^{\prime} 17^{\prime \prime}$ & 160 & 11.1 & DCF \\
\hline $5 \mathrm{~N}$ & $67^{\circ} 58^{\prime} 06^{\prime \prime}$ & $32^{\circ} 58^{\prime} 38^{\prime \prime}$ & 140 & 5 & IB \\
\hline $1 \mathrm{~N}$ & $67^{\circ} 56^{\prime} 04^{\prime \prime}$ & $32^{\circ} 58^{\prime} 19^{\prime \prime}$ & 180 & 1.6 & IB \\
\hline $1 \mathrm{~S}$ & $67^{\circ} 54^{\prime} 49^{\prime \prime}$ & $32^{\circ} 48^{\prime} 41^{\prime \prime}$ & 180 & 0.7 & BTC \\
\hline $4 \mathrm{~S}$ & $67^{\circ} 52^{\prime} 59^{\prime \prime}$ & $32^{\circ} 46^{\prime} 40^{\prime \prime}$ & 210 & 4.3 & BTC \\
\hline $8 \mathrm{~S}$ & $67^{\circ} 51^{\prime} 01^{\prime \prime}$ & $32^{\circ} 48^{\prime} 10^{\prime \prime}$ & 240 & 7.5 & IB \\
\hline $13 \mathrm{~S}$ & $67^{\circ} 48^{\prime} 03^{\prime \prime}$ & $32^{\circ} 47^{\prime} 05^{\prime \prime}$ & 140 & 13.0 & BTC \\
\hline $18 \mathrm{~S}$ & $67^{\circ} 45^{\prime} 31^{\prime \prime}$ & $32^{\circ} 48^{\prime} 29^{\prime \prime}$ & 210 & 17.5 & DCF \\
\hline $21 \mathrm{~S}$ & $67^{\circ} 43^{\prime} 29^{\prime \prime}$ & $32^{\circ} 50^{\prime} 34^{\prime \prime}$ & 250 & 20.8 & DCF \\
\hline $27 \mathrm{~S}$ & $67^{\circ} 40^{\prime} 39^{\prime \prime}$ & $32^{\circ} 49^{\prime} 27^{\prime \prime}$ & 220 & 26.7 & DCF \\
\hline $31 \mathrm{~S}$ & $67^{\circ} 38^{\prime} 21^{\prime \prime}$ & $32^{\circ} 45^{\prime} 00^{\prime \prime}$ & 170 & 31.1 & $\mathrm{CF}$ \\
\hline $40 \mathrm{~S}$ & $67^{\circ} 34^{\prime} 36^{\prime \prime}$ & $32^{\circ} 33^{\prime} 03^{\prime \prime}$ & 140 & 39.7 & $\mathrm{CF}$ \\
\hline
\end{tabular}

${ }^{1}$ The site codes indicate approximate distance from the smelter in $\mathrm{km}$ and direction to the north or south of the smelter. ${ }^{2}$ Habitat types: BTC - birch- and willow-dominated transitional community, CF - coniferous forest, DCF - coniferous forest visibly damaged by pollution, IB - industrial barren. 


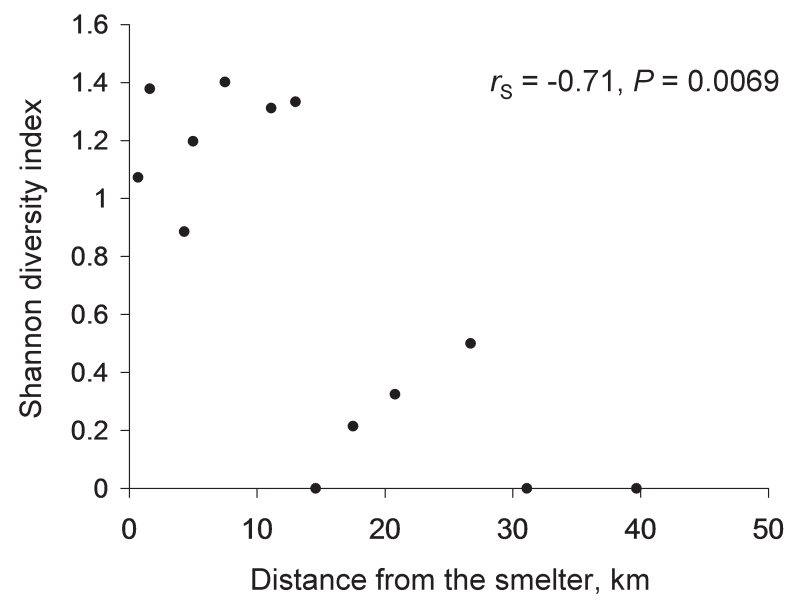

Fig. 2. The relationships between the diversity of Coccinellidae and distance from the smelter.

distances from the smelter separately for each species of Coccinellidae and Shannon's index.

The overall effect of pollution on the abundance of Coccinellidae was revealed by meta-analysis of species-specific coefficients of Spearman rank correlation between the numbers of collected individuals and distances from the smelter. This method increases the statistical power of the overall conclusion relative to the statistical power of the individual correlations. The correlation coefficients were $z$-transformed and weighted by their sample sizes (i.e. by the numbers of study sites) using the standard procedure in the MetaWin 2.0 program (Rosenberg et al., 2000) to calculate effect sizes (ES). The meta-analysis was performed using a random effects model. The effect was considered statistically significant if its $95 \%$ confidence interval $\left(\mathrm{CI}_{95}\right)$ did not include zero. The variation in the $\mathrm{ES}$ values among ladybird species was explored by calculating the total heterogeneity index $\left(Q_{\mathrm{T}}\right)$ and testing it against the $\chi^{2}$ distribution (Gurevitch \& Hedges, 2001).

\section{RESULTS}

A total of 216 adult specimens of eight species of Coccinellidae were collected from 13 sites during the 13 study years (Tables 2-3); larvae of ladybirds were occasionally

TABLE 2. Ambient air temperature on the day of sampling, the sum of temperatures above $5^{\circ} \mathrm{C}$ accumulated up to the day on which the samples were collected (dd5) and the number of Coccinellidae collected in all 13 study sites.

\begin{tabular}{lcccc}
\hline Year & Date of census & $\begin{array}{c}\text { Temperature } \\
\left({ }^{\circ} \mathrm{C}\right)\end{array}$ & dd5 & $\begin{array}{c}\text { No. of } \\
\text { beetles }\end{array}$ \\
\hline 2002 & 11 June & 13.5 & 132 & 29 \\
2003 & 18 June & 9.5 & 96 & 10 \\
2004 & 21 June & 16 & 103 & 11 \\
2005 & 16 June & 16 & 155 & 8 \\
2006 & 21 June & 19.3 & 196 & 22 \\
2007 & 17 June & 8.3 & 106 & 11 \\
2008 & 18 June & 14.9 & 64 & 26 \\
2009 & 30 June & 16.6 & 206 & 10 \\
2010 & 26 June & 15.6 & 204 & 16 \\
2011 & 18 June & 9.2 & 177 & 29 \\
2012 & 26 June & 15.5 & 228 & 6 \\
2013 & 14 June & 13.2 & 219 & 12 \\
2014 & 11 June & 16.9 & 139 & 26 \\
\hline
\end{tabular}

observed on willows but were not sampled. The numbers of collected specimens did not vary among the study years (Table $2 ; \chi^{2}=18.9, d f=12, P=0.09$ ) and did not depend on either ambient air temperature on the day of sampling $\left(r_{\mathrm{S}}=-0.10, n=13\right.$ years, $\left.P=0.74\right)$ or on $\mathrm{dd} 5\left(r_{\mathrm{S}}=-0.25\right.$, $n=13, P=0.41)$.

The total numbers of Coccinellidae varied among the study sites $\left(\chi^{2}=43.0, d f=12, P<0.0001\right)$, with maximum values recorded at the most disturbed (barren) sites (Table 3 ). The diversity of Coccinellidae decreased from the most to the least polluted sites (Fig. 2), and only the most abundant species, $C$. quatuordecimguttata, was recorded at sites located over $30 \mathrm{~km}$ from the smelter.

Only three of the eight species of Coccinellidae significantly decreased in abundance with increasing distance from the smelter (Table 3). Still, the overall effect of distance on the abundance of Coccinellidae was significant $\left(\mathrm{ES}=-0.43, \mathrm{CI}_{95}=-0.48 \ldots-0.15\right)$ and homogeneous $\left(Q_{\mathrm{T}}\right.$ $=12.6, d f=7, P=0.08)$.

\section{DISCUSSION}

One of the eight species of ladybirds collected around Monchegorsk, C. quatuordecimguttata, feeds primarily on psyllids. The remaining species, by contrast, feed on aphids (Semjanov, 1965), which are common and diverse on willows in the study area (Stekolshchikov, 2012). Six of the eight species of ladybirds collected around Monchegorsk are classified as generalists (Hodek \& Evans, 2012); therefore, some of them may also feed on eggs and young larvae of willow-feeding leaf beetles (Phratora vitellinae L., Chrysomela lapponica L. and Plagiodera versicolora Laich.). Intriguingly, C. trifasciata, a specialist species reported earlier only from conifers (Semjanov, 1965), was found on willows in the barren sites near Monchegorsk, where conifers are completely lacking.

The average numbers of the collected Coccinellidae were low ( 0.7 specimens of the most abundant species, $C$. quatuordecimguttata, per site per year), allowing the classification of all ladybirds as rare in the study area. For comparison, willow-feeding leaf beetles were more than 100 times more abundant than ladybirds: during the same censuses, 79.4 specimens of $P$. vitellinae, 15.1 of $C$. lapponica and 6.3 of $P$. versicolora were recorded per site per year (M. Kozlov, unpubl. data). The absence of effects of date of sampling or ambient air temperature on the numbers of ladybirds justified the pooling of data across study years.

Earlier studies of ladybirds in the environs of industrial polluters yielded contradictory results. Species richness of predatory Coccinellidae strongly decreased in forested areas around a coking plant in Knurów, Poland (Gałecka, 1980), slightly decreased in Scots pine (Pinus sylvestris L.) forests near a chemical plant in Tomaszów Mazowiecki, Poland (Wiąckowski, 1978), and slightly increased in beech (Fagus sylvatica L.) forests near an aluminium plant in Žiar nad Hronom, Slovakia (Zelinková et al., 2004). Furthermore, a meta-analysis showed that the overall effect of pollution on the diversity of terrestrial arthropods, measured by both species richness and the Shannon's in- 
TABLE 3. Numbers of beetles of eight species of Coccinellidae collected from 2002-2014, and Spearman rank correlations $\left(r_{\mathrm{S}}\right)$ of site-specific data with the distance from the smelter.

\begin{tabular}{|c|c|c|c|c|c|c|c|c|}
\hline \multirow{2}{*}{ Site code $^{1}$} & \multicolumn{8}{|c|}{ Numbers of individuals ${ }^{2}$} \\
\hline & dece & frig & hier & quat & sept & trif & unde & vari \\
\hline $15 \mathrm{~N}$ & 0 & 0 & 0 & 2 & 0 & 0 & 0 & 0 \\
\hline $11 \mathrm{~N}$ & 0 & 2 & 1 & 3 & 3 & 0 & 0 & 0 \\
\hline $5 \mathrm{~N}$ & 0 & 5 & 0 & 12 & 2 & 1 & 0 & 21 \\
\hline $1 \mathrm{~N}$ & 0 & 5 & 1 & 9 & 2 & 2 & 0 & 18 \\
\hline $1 \mathrm{~S}$ & 0 & 2 & 0 & 8 & 0 & 2 & 0 & 1 \\
\hline $4 \mathrm{~S}$ & 1 & 0 & 0 & 8 & 0 & 1 & 0 & 1 \\
\hline $8 \mathrm{~S}$ & 0 & 6 & 1 & 4 & 0 & 1 & 0 & 3 \\
\hline $13 \mathrm{~S}$ & 1 & 3 & 0 & 10 & 2 & 0 & 0 & 4 \\
\hline $18 \mathrm{~S}$ & 0 & 0 & 0 & 17 & 0 & 0 & 1 & 0 \\
\hline $21 \mathrm{~S}$ & 0 & 0 & 1 & 9 & 0 & 0 & 0 & 0 \\
\hline $27 \mathrm{~S}$ & 0 & 0 & 0 & 4 & 0 & 1 & 0 & 0 \\
\hline $31 \mathrm{~S}$ & 0 & 0 & 0 & 32 & 0 & 0 & 0 & 0 \\
\hline $40 \mathrm{~S}$ & 0 & 0 & 0 & 3 & 0 & 0 & 0 & 0 \\
\hline$r_{\mathrm{S}}$ & -0.23 & -0.66 & -0.22 & -0.02 & -0.38 & -0.74 & 0.15 & -0.74 \\
\hline$P$ & 0.45 & 0.01 & 0.47 & 0.95 & 0.20 & 0.0041 & 0.61 & 0.0037 \\
\hline
\end{tabular}

${ }^{1}$ The site codes indicate approximate distance from the smelter in $\mathrm{km}$ and direction to the north or south of the smelter. ${ }^{2}$ Species of Coccinellidae: dece - Adalia decempunctata (L.); frig - A. bipunctata frigida (Schneider); hier - Coccinella hieroglyphica L.; quat - Calvia quatuordecimguttata (L.); sept - Coccinella septempunctata L.; trif - C. trifasciata L.; unde - C. undecimpunctata L.; vari Hippodamia variegata (Goeze).

dex, was not statistically significant (Zvereva \& Kozlov, 2010). Therefore, the significant increase in the diversity of ladybirds near the Monchegorsk smelter and the association of seven of the eight recorded species of Coccinellidae with severely and/or moderately polluted sites was somewhat surprising.

The overall abundance of Coccinellidae increased by a factor of 4.7 near an aluminium plant in Žiar nad Hronom (Zelinková et al., 2004) and by a factor 2.4 near a zinc and lead smelter in Miasteczko Śląskie (Chlodny, 1976), but decreased to 0.7 near a coking plant in Knurów and by half near a chemical plant in Tomaszów Mazowiecki compared to control sites (Wiąckowski, 1978; Gałecka, 1980). Thus, a positive effect of pollution on the abundance of ladybirds around the Monchegorsk smelter is within the range of variation observed among the impact zones of different industrial polluters.

The absence of among-species heterogeneity indicates that, in spite of variation in species-specific correlations between beetle numbers and distance from the smelter, Coccinellidae in subarctic forests generally benefit from pollution-induced environmental changes. This result contradicts the findings of a recent meta-analysis (Zvereva \& Kozlov, 2010), which reported a pronounced decrease in population densities of predatory arthropods near industrial polluters; i.e. the positive response of ladybirds to pollution is exceptional among invertebrate predators. Thus, the same level of pollution may create an enemy-free space for some groups of plant-feeding insects, such as leaf beetles and leaf mining moths (Zvereva \& Kozlov, 2000, 2006), and increase the impacts of predators on other groups of herbivores, particularly on aphids.

The pollution-induced increase in abundance of plantfeeding insects, aphids in particular (Zvereva \& Kozlov, 2010), in polluted habitats is often attributed to stress ex- perienced by their host plants (Whittaker \& Warrington, 1990). However, willows near the Monchegorsk smelter do not exhibit any signs of stress; indeed, pollution-induced habitat deterioration may even stimulate growth of willow leaves and shoots (Zvereva et al., 1997). Furthermore, insect folivory on willows in these sites is independent of the level of pollution (Kozlov, 2015), suggesting that changes in prey availability are unlikely to drive an increase in diversity and abundance of ladybirds with increasing pollution.

The detected association of Coccinellidae with polluted sites may be explained by the release of these rare predators from competition for prey, due to the pollution-induced decline of other more abundant generalist predators, in particular ants. Nevertheless, other groups of rare invertebrate predators need to be studied in polluted habitats to verify this hypothesis. On the other hand, the conclusions of the earlier meta-analysis might be biased because published data on predators primarily concern epigeal organisms (Zvereva \& Kozlov, 2010), which may respond to pollution differently than arboreal predators. Last but not least, studies reporting 'exceptional' patterns, such as an increase in density of predatory invertebrates in polluted habitats, could have been eliminated during the peer review process: the adverse effects of pollution on soil arthropods (mostly predators) reported in studies published in ISI journals were twice as strong, on average, as the effects recorded in studies published in local journals and conference proceedings (Zvereva \& Kozlov, 2010).

It is seldom appreciated that severely contaminated sites and other post-industrial landscapes may support regionally rare and endangered species (Johnson et al., 1978; Eyre \& Luff, 1995). One of the most striking examples is the occurrence of viable populations of a rare moth, Sesia bembeciformis ( $\mathrm{Hb}$.), in the industrial barrens around Monchegorsk (sites 1N, 4S and 8S in Fig. 1: Kozlov \& 
Kullberg, 2011), because this species had earlier been considered extinct in Finland (Rassi et al., 1985). Similarly, the buprestid beetle Melanopila formaneki (Jakobson) was discovered for the first time in Finland in a semi-barren site near the Harjavalta smelter (Heliövaara et al., 1990). The association of rare species of ladybirds with severely disturbed habitats supports the hypothesis (Kozlov \& Zvereva, 2007; Kozlov \& Kullberg, 2011) that the presence of some species, including regionally rare and endangered ones, is favoured by pollution-induced habitat deterioration. This presumably arises due to factors such as changes in microclimate following tree canopy disintegration, increased availability of food, decreased pressure from natural enemies and/or decreased competition.

To conclude, some groups of rare predators, in particular Coccinellidae, may benefit from environmental changes caused by severe industrial pollution, although abundant generalist predators generally are adversely affected by these changes. This result indicates that the effects of disturbances on the abundance of different organisms should be analyzed at the species level, especially for rare species, rather than by aggregating the data by high-rank taxa, functional groups or feeding guilds.

ACKNOWLEDGEMENTS. I am thankful to V. Zverev, E. Melnikov and E. Zvereva for assistance with collecting ladybirds, to H. Silfverberg and J. Mattila for the identifications of Coccinellidae, and to E. Zvereva and two anonymous reviewers for useful comments on an earlier draft of the manuscript. This work was made possible due to financial support from the EC through the BALANCE project (EVK2-2002-00169), NordForsk (through a visiting professorship grant to M. Kozlov) and the Academy of Finland (projects 122133, 124152, 126045, 268124 and 276671, and researcher exchange grants).

\section{REFERENCES}

Alstad D.N., Edmunds G.F. \& Weinstein L.H. 1982: Effects of air pollutants on insect populations. - Annu. Rev. Entomol. 27: 369-384.

Chlodny J. 1976: The numbers of aphids (Aphididae) and the concurrent fauna in young plantation of common birch (Betula verrucosa Ehrh.) in the Upper Silesian industrial district. In Sander H. (ed.): Entomologia a Ochrona Šrodowiska. [Entomology and Nature Protection.] Panstwowe wydawnictwo naukowe, Warszawa, pp. 41-47 [in Polish, English abstr.].

Eyre M.D. \& Luff M.L. 1995: Coleoptera on post-industrial land: a conservation problem? - Land Contam. Reclam. 3: 132-134.

GAŁECKA B. 1980: Structure and functioning of community of Coccinellidae (Coleoptera) in industrial and agricultural-forest regions. - Pol. Ecol. Stud. 6: 717-734.

Gaston K.J. 1994: Rarity. Chapman \& Hall, London, 192 pp.

Gurevitch J. \& Hedges L.V. 2001: Meta-analysis. Combining the results of independent experiments. In Schneider S.M. \& Gurevitch J. (eds): Design and Analysis of Ecological Experiments. Oxford University Press, Oxford, pp. 347-369.

HeliöVAara K. \& VÄISÄNEN R. 1993: Insects and Pollution. CRC, Boca Raton, FL, 393 pp.

Heliövaara K., Terho E. \& Koponen M. 1982: Parasitism in the eggs of the pine bark-bug, Aradus cinnamomeus (Heteroptera: Aradidae). - Ann. Entomol. Fenn. 48: 31-32.
HeliövaAra K., VÄIsänen R. \& Mannerkoski I. 1990: Melanophila formaneki (Jakobson) (Coleoptera, Buprestidae) new to Finland. - Entomol. Fenn. 1: 221-225.

Hodek I. \& Evans E.W. 2012: Food relationships. In Hodek I., van Emden H.F. \& Honěk A. (eds): Ecology and Behaviour of the Ladybird Beetles (Coccinellidae). Wiley-Blackwell, Chichester, pp. 141-274.

Johnson M.S., Putwain P.D. \& Holliday R.J. 1978: Wildlife conservation value of derelict metalliferous mine workings in Wales. - Biol. Conserv. 14: 131-148.

Kozlov M.V. 2015: Insect herbivory on two willow species in northern Europe is independent of pollution load. - Boreal Environ. Res. 20: 423-430.

Kozlov M.V. \& Kullberg J. 2011: New and interesting records of Lepidoptera from the Kola Peninsula, Northwestern Russia, in 2000-2009. - Entomol. Fenn. 21: 254-272.

KozLov M.V. \& Zvereva E.L. 2007: Industrial barrens: extreme habitats created by non-ferrous metallurgy. - Rev. Environ. Sci. BioTechnol. 6: 231-259.

Kozlov M.V. \& Zvereva E.L. 2011: A second life for old data: global patterns in pollution ecology revealed from published observational studies. - Environ. Poll. 159: 1067-1075.

Kozlov M.V. \& Zvereva E.L. 2015: Pollution in forests. In Peh K., Corlett R. \& Bergeron Y. (eds): Handbook of Forest Ecology. Routledge, London, pp. 438-453.

Kozlov M.V., Zvereva E.L. \& Zverev V.E. 2009: Impacts of Point Polluters on Terrestrial Biota: Comparative Analysis of 18 Contaminated Areas. Springer, Dordrecht, xvii +466 pp.

Lavelle P., Decaens T., Aubert M., Barot S., Blouin M., Bureau F., Margerie P., Mora P. \& Rossi J.P. 2006: Soil invertebrates and ecosystem services. - Eur. J. Soil Biol. 42: S3-S15.

Lavergne S., Thuiller W., Molina J. \& Debussche M. 2005: Environmental and human factors influencing rare plant local occurrence, extinction and persistence: a 115-year study in the Mediterranean region. - J. Biogeogr. 32: 799-811.

Maleque M.A., IshiI H.T. \& Maeto K. 2006: The use of arthropods as indicators of ecosystem integrity in forest management. - J. Forest 104: 113-117.

Mouillot D., Bellwood D.R., Baraloto C., Chave J., Galzin R., Harmelin-Vivien M., Kulbicki M., Lavergne S., Lavorel S., Mouquet N., Paine C.E.T., Renaud J. \& Thuiller W. 2013: Rare species support vulnerable functions in high-diversity ecosystems. - PLoS Biol. 11(5): e1001569.

Pannucci C.J. \&Wilkins E.G. 2010: Identifying and avoiding bias in research. - Plastic Reconstr. Surg. 126: 619-625.

Rassi P., Alanen A., Kemppainen E., Vickholm M., Väisänen R. (eds) 1985: Uhanalaisten Eläinten ja Kasvien Suojelutoimikunnan Mietintö. II. Suomen Uhanalaiset Eläimet. [Report of the Committee on Protection of Endangered Animals and Plants. II. Endangered Animals of Finland.] Ympäristöministeriö, Helsinki, 466 pp. [in Finnish].

Rosenberg M.S., Adams D.C. \& Gurevitch J. 2000: MetaWin: Statistical Software for Meta-Analysis, Ver. 2.0. Sinauer, Sunderland.

Sekercioglu C.H., Schneider S.H., Fay J.P. \& Loarie S.R. 2008: Climate change, elevational range shifts, and bird extinctions. - Conserv. Biol. 22: 140-150.

SElikhovkin A.V. 1985: Factors controlling lepidopteran population density in an industrially polluted area. In Solovjev V.A. (ed.): Ecology and Protection of Forests: Interaction of Forest Ecosystem Components. Forest Technical Academy, Leningrad, pp. 123-127 [in Russian].

Semjanov V.P. 1965: Fauna and stational distribution of ladybirds (Coleoptera, Coccinellidae) in the Leningrad region. - Rev. Entomol. URSS 44: 315-323 [in Russian, English abstr.]. 
Stekolshchikov A.V. 2012: Annotated list of aphids (Homoptera, Aphidinea) of the Lapland Reserve. - Proc. Lapland State Nature Biosphere Reserve 6: 385-411 [in Russian].

WhitTAKER J.B. \& WARRINGTON S. 1990: Effects of atmospheric pollutants on interactions between insects and their food plants. In Burdon J.J. \& Leather S.R. (eds): Pests, Pathogens and Plant Communities. Blackwell, Oxford, pp. 97-110.

WiĄCKOWSKI S.K. 1978: Impact of industrial air pollution upon parasites of pine bud moth (Exoteleia dodecella L.), aphid predators, and certain other insects occurring on pine in vicinity of Tomaszow Maz. - Folia Forestal. Pol. (A) 23: 175-187 [in Polish, English abstr.].

WiLson E.O. 1987: The little things that run the world (the importance and conservation of invertebrates). - Conserv. Biol. 1: $344-346$.

Zelinková D., Kulfan J. \& Zach P. 2004: Coccinellid beetles (Coleoptera: Coccinellidae) on beech trees affected by immissions from an aluminium plant. - Entomofauna Carpath. 16: 71-73.

ZVEREV V.E. 2009: Mortality and recruitment of mountain birch (Betula pubescens ssp. czerepanovii) in the impact zone of a copper-nickel smelter in the period of significant reduction of emissions: the results of 15 -year monitoring. - Russ. J. Ecol. 40: 254-260.

Zvereva E.L. \& Kozlov M.V. 2000: Effects of air pollution on natural enemies of the leaf beetle Melasoma lapponica. $-J$. Appl. Ecol. 37: 298-308.

Zvereva E.L. \& Kozlov M.V. 2006: Top-down effects on population dynamics of Eriocrania miners (Lepidoptera) under pollution impact: does enemy-free space exist? - Oikos 115: 413-426.

Zvereva E.L. \& Kozlov M.V. 2010: Responses of terrestrial arthropods to air pollution: a meta-analysis. - Environ. Sci. Pollut. Res. 17: 297-311.

Zvereva E.L., Kozlov M.V. \& Neuvonen S. 1995: Population density and performance of Melasoma lapponica (Coleoptera, Chrysomelidae) in surroundings of smelter complex. - Environ. Entomol. 24: 707-715.

Zvereva E.L., Kozlov M.V. \& Haukioja E. 1997: Stress responses of Salix borealis to pollution and defoliation. - J. Appl. Ecol. 34: 1387-1396.

Received March 19, 2015; revised and accepted May 16, 2015 Prepublished online July 10, 2015 